Vol. 2 No. 1 Februari 2022, e-ISSN : 2797-0140 | p-ISSN : 2797-0590

\title{
PENGGUNAAN MEDIA GOOGLE CLASSROOM BERBANTU LIVEWORKSHEETS UNTUK MENINGKATKAN HASIL BELAJAR IPA MATERI KEMAGNETAN SISWA SMP
}

\author{
MUNTIANI ROHMAH
}

SMP Negeri 17 Malang

e-mail: muntirohmah@gmail.com

\begin{abstract}
ABSTRAK
Penelitian ini bertujuan untuk meningkatkan hasil belajar IPA siswa kelas XA SMP Negeri 17 Malang melalui penggunaan media Google Classroom Berbantu Liveworksheets. Subjek penelitian ini adalah siswa kelas IXA berjumlah 32 siswa. Penelitian ini merupakan penelitian tindakan kelas (Classroom Action Research) yang terdiri dari empat komponen yang merupakan siklus mulai dari tahap perencanaan, pelaksanaan tindakan, observasi, refleksi dan revisi. Penelitian ini dibagi menjadi 2 siklus yaitu siklus I dan II dan masing-masing siklus terdiri dari 2 pertemuan. Seluruh data diperoleh melalui observasi, tes dan angket. Penelitian ini menggunakan analisis data secara kuantitatif. Hasil penelitian menunjukkan bahwa penggunaan Media Google Classroom Berbantu Liveworksheets dapat meningkatkan proses pembelajaran IPA materi Kemagnetan kelas IXA. Hasil penelitian tindakan kelas ini menunjukkan bahwa (1) Proses pembelajaran IPA dengan menggunakan media Google Classroom Berbantu Liveworksheets, membuat siswa aktif, senang dan tertarik. (2) Hasil belajar yang dicapai siswa meningkat dengan nilai rata-rata kelas 76,5\% (Baik) dan hasil observasi keaktifan siswa dengan skor total 80 (Sangat aktif).
\end{abstract}

Kata Kunci: Google Classroom, Liveworksheets, Hasil Belajar

\section{ABSTRACT}

This study aims to improve the science learning outcomes of class XA students of SMP Negeri 17 Malang through the use of Google Classroom Assisted Liveworksheets media. The subjects of this research were 32 students of class IXA. This research is a classroom action research (Classroom Action Research) which consists of four components which are a cycle starting from the planning stage, action implementation, observation, reflection and revision. This research was divided into 2 cycles, namely cycles I and II and each cycle consisted of 2 meetings. All data were obtained through observation, tests and questionnaires. This study uses quantitative data analysis. The results showed that the use of Google Classroom Media Assisted with Liveworksheets could improve the science learning process for magnetism in class IXA. The results of this classroom action research show that (1) The science learning process using Google Classroom Assisted Liveworksheets media makes students active, happy and interested. (2) The learning outcomes achieved by students increase with an average grade of $76.5 \%$ (Good ) and the results of observations of student activity with a total score of 80 (very active).

Keywords: Google Classroom, Liveworksheets, Learning Outcomes

\section{PENDAHULUAN}

Proses belajar yang berhasil dinilai dari penguasaan materi pelajaran oleh peserta didik. Selain itu, keberhasilan peserta didik dapat dilihat dari penguasaan materi yang dinyatakan pada prolehan nilai. Pemilihan metode dan media yang tepat dan menarik,menjadikan adanya interaksi yang edukatif sehingga peserta didik berkembang kreativitasnya dan mudah menerima pelajaran yang diberikan. Dalam Kompetensi Inti dan Kompetensi Dasar pelajaran IPA pada Kurikulum 2013 untuk kondisi khusus (lampiran Keputusan Kepala Badan Penelitian Dan Pengembangan dan Perbukuan nomor 018/H/KR/2020), disebutkan bahwa idealnya peserta didik kelas IX mampu memahami dan menerapkan pengetahuan (faktual, konseptual, dan prosedural) berdasarkan rasa ingin tahunya tentang ilmu pengetahuan, teknologi, seni, budaya terkait fenomena dan kejadian tampak mata, serta mampu menerapkan konsep kemagnetan, 
induksi elektromagnetik, dan pemanfaatan medan magnet dalam kehidupan sehari - hari. Idealnya, setelah peserta didik mendapatkan pengetahuan tentang kemagnetan, mereka dapat membuat rancangan karya sederhana yang memanfaatkan prinsip elektromagnet dan/ atau induksi elektromagnetik.

Virus corona yang menyerang seluruh negara di dunia sejak tahun 2019 , dan masuk ke Indonesia serta dirasakan dampaknya mulai tahun 2020. Sehubungan dengan itu ,dunia pendidikan juga terimbas oleh pandemi covid 19 tersebut, tahun 2020 ini merupakan tahun yang hampir semua program kerja Nasional banyak yang tidak terlaksana, dalam dunia pendidkan diantaranya UN ditiadakan dan US juga dengan alternatif pilihan disesuaikan dengan Sekolah masing -masing, semua agenda kegiatan belajar dihentikan, Peserta Didik, Guru,Kepala Sekolah dan Pengawas sejak tanggal 16 Maret 2020 melaksakan pembelajaran dari rumah.Agenda Tahunan Peserta Didik semua dibatalkan atas dasar penyelamatan hidup manusia agar terhindar dari corona. Dengan penuh harapan proses pembelajaran tahun ajaran 2021/2022 bisa normal kembali, tetapi ternyata rencana pemerintah untuk mengijinkan sekolah tatap muka tertunda karena kasus Covid justru meningkat menjelang pertemuan tatap muka terbatas yang disingkat dengan PTMT. Sejak Bulan September 2021 PTMT boleh dilaksanakan yang pelaksanaan dengan pembatasan jumlah siswa untuk tingkat SMP sebesar $50 \%$ dari jumlah peserta didik. Memasuki semester genap 2021/2022 ada perkembangan kebijakan dimana PTMT tidak lagi $50 \%$ tetapi sudah $100 \%$ tidak ada lagi belajar di rumah semua masuk secara penuh.

Berdasarkan pengalaman peneliti yang mengajar di kelas IX A pada semester gasal Tahun Pelajaran 2021/2022 dengan menggunakan media Google Classroom dan Google Formulir, hasil belajar siswa rata-rata masih belum mecapai standart KKM yaitu (75). Hal itu terbukti dengan diperolehnya hasil rata -rata Nilai Ulangan Harian $(71,74)$, rata -rata Nilai PTS $(70,7)$, dan rata - rata Nilai PAS $(70,2)$. Untuk itu peneliti mencoba mencari solusi dengan menggunakan media lain dengan harapan akan memberi motivasi kepada siswa untuk lebih tertarik belajar dan akhirnya bisa meningkatkan hasil belajarnya sehingga minimal bisa mencapai KKM dan syukur bila bisa mencapai diatas KKM.

Keberhasilan pembelajaran mata pelajaran IPA akan tercapai apabila seorang guru mampu menguasai dan mengkoordinir metode serta media pembelajaran dengan baik melalui pembelajaran tatap muka maupun jarak jauh dimasa pandemi ini. Sedangkan faktor penyebab kegagalan bila seorang guru tidak mampu menciptakan pembelajaran yang kondusif dan interaktif serta menjadikan siswa bertanggung jawab untuk belajar mandiri. Seiring berjalannya waktu, segala hambatan sedikit demi sedikit teratasi, antara lain guru mencari solusi dengan tetap menggunakan media Google Classroom, tetapi dibantu media daring lainnya, seperti Google Form , quizizz, liveworksheets, dan lainnya.

Menurut Lisnuriyanih (2021), Liveworksheets adalah salah satu platform yang menyediakan tempat untuk guru membuat $e$-worksheet atau lembar kerja yang dapat dikerjakan secara online. Aplikasi ini menarik ,kemudian sangat mudah digunakan. Liveworksheet adalah aplikasi yang dapat digunakan untuk membuat materi dan Lembar Kerja Peserta Didik (LKPD) interaktif secara online. Depdiknas (Darusman, 2008) menyatakan LKPD adalah lembaran yang berisikan pedoman bagi siswa untuk melaksanakan kegiatan yang terprogram. LKPD berfungsi menjembatani kegiatan belajar mengajar sehingga akan terbentuk interaksi yang efektif antara peserta didik dengan pendidik, hal ini dapat meningkatkan aktivitas peserta didik dalam peningkatan prestasi belajar. Liveworksheets dapat menampilkan materi berupa video, mp3, gambar, serta simbol-simbol menarik lainnya yang dapat menambah daya tarik. Guru dapat membuat LKPD secara aktif pada liveworksheets. Peserta didik dapat mengerjakan berbagai bentuk pertanyaan seperti pilihan ganda, pilihan dengan bentuk drop down, pertanyaan terbuka, kotak centang, menjodohkan dengan menarik garis, pertanyaan bentuk drag and drop dan bentuk lain sesuai dengan kreatifitas pembuat. LKPD yang ditampilkan melalui liveworksheets sangat mudah dibuat. Kunci jawaban bisa langsung dimasukkan pada aplikasi, sehingga ketika peserta didik selesai mengerjakan nilai dapat 
langsung muncul. Beragam bentuk pertayaan pada aplikasi ini dapat membuat pembelajaran IPA menjadi lebih menarik.

Menurut Hazlita (2021) "Dari hasil implementasi pembelajaran dalam jaringan dengan menggunakan instagram dan liveworksheets pada masa pandemi di SMP Negeri 1 Selat Nasik diperolah data bahwa ada perbedaan jumlah partisipan yaitu $48,44 \%$ pada pembelajaran dalam jaringan dengan metode konvensional dan $74,29 \%$ pada pembelajaran dalam jaringan menggunakan instagram dan liveworksheets. Dengan demikian bisa disimpulkan bahwa penggunaan instagram dan liveworksheets dalam pembelajaran e-learning di masa pandemi dapat meningkatkan banyak partisipan. Selain itu, masih terdapat $25,71 \%$ peserta didik yang menjadi non partisipan. Dari hasil wawancara ditarik kesimpulan bahwa ada beberapa faktor yang mengakibatkan peserta didik menjadi non partisipan pada pembelajaran daring menggunakan instagram dan liveworksheets. Faktor-faktor tersebut adalah keterbatasan fasilitas baik ponsel pintar maupun sinyal, masih terjadi kesalahan pada saat memasukkan data di Liveworksheets serta kurangnya semangat, kepedulian dan kesadaran peserta didik untuk tetap belajar selama pembelajaran jarak jauh berlangsung. Karenanya perlu pendekatan lebih lagi kepada peserta didik agar mau tetap semangat dan aktif pada saat pembelajaran dalam jaringan selama masa pandemi". Dari dua rujukan diatas peneliti dapat menyimpulkan penggunaan liveworksheets dapat digunakan untuk meningkatkan hasil belajar siswa kelas IX A SMP Negeri 17 Malang.

Uraian di atas, menjadi landasan penulis melakukan penelitian tindakan kelas dengan judul "Penggunaan Media Google Classroom berbantu liveworksheets untuk meningkatkan hasil belajar IPA materi Kemagnetan pada peserta didik kelas IXA SMP Negeri 17 Malang semester genap Tahun Pelajaran 2021/2022”. Adapun rumusan masalah adalah (1).Bagaimana proses pembelajaran IPA materi Kemagnetan di Kelas IX A SMP Negeri 17 Malang dengan menggunakan media google Classroom berbantu liveworksheets?,(2) Bagaimana hasil belajar siswa di Kelas IX A SMP Negeri 17 Malang pada pembelajaran IPA materi Kemagnetan dengan menggunakan media google Classroom berbantu liveworksheets?.

Tujuan Penelitian adalah (1). untuk mendiskripsikan proses pembelajaran IPA materi Kemagnetan di Kelas IX A SMP Negeri 17 Malang dengan menggunakan media google Classroom berbantu liveworksheets, (2) untuk mengetahui hasil belajar siswa di Kelas IX A SMP Negeri 17 Malang pada pembelajaran IPA materi Kemagnetan dengan menggunakan media google Classroom berbantu liveworksheets.

\section{METODE PENELITIAN}

Subjek penelitian ini adalah seluruh siswa kelas IX.A SMP Negeri 17 Malang, semester genap tahun pelajaran 2021/2022, jumlah siswa 32 anak terdiri dari siswa laki- laki 14 anak, siswa perempuan 18 anak. Waktu pelaksanaan penelitian ini dilaksanakan kurang lebih selama tiga bulan ,yaitu mulai bulan Desember 2021 sampai dengan Februari 2022. Penelitian ini dilaksanakan di SMP Negeri 17 Malang, Jalan Pelabuhan Tanjung Priok 170, Bakalan Krajan, Sukun Malang. Alasan dilaksanakan di sekolah tersebut karena peneliti adalah tenaga pengajar di sekolah tersebut.Rancangan penelitian tindakan kelas yang dilaksanakan terdiri atas dua siklus, dimana siklus pertama dan siklus berikutnya merupakan rangkaian yang saling berkaitan. Gambaran umum yang dilakukan pada setiap siklus adalah: Perencanaan, pelaksanaan, pengamatan, dan refleksi. Pada Tahap Perencanaan dilakukan hal berikut : 1) Melakukan observasi ke kelas IX A yang akan diteliti untuk mengetahui masalah-masalah yang sering muncul pada saat proses belajar mengajar berlangsung secara luring dan daring dengan PTMT , khususnya pelajaran IPA, 2) Menetapkan materi yang akan diajarkan pada penelitian ini, yaitu kemagnetan, 3) Menyusun silabus dan RPP (Rencana Pelaksanaan Pembelajaran) untuk materi kemagnetan, 4) Membuat lembar observasi untuk mengetahui keaktifan siswa selama proses belajar mengajar berlangsung, 5) Menyusun materi dan soal untuk diaplikasikan dengan media liveworksheets untuk materi kemagnetan, 6) Menyusun alat evaluasi yang akan diberikan pada akhir siklus 1. Pada Tahap Tindakan kegiatan belajar mengajar dilaksanakan 
secara luring sebanyak 4 (empat) kali pertemuan, satu jam pelajaran selama 40 (empat puluh) menit

PadaTahap Observasi, Observasi dilaksanakan bersamaan dengan pelaksanaan tindakan siklus I mulai dari pertemuan pertama hingga kedua. Observasi ini digunakan untuk merekam segala aktivitas peserta didik dan kinerja guru selama tindakan pembelajaran dengan menggunakan google clasroom berbantu liveworksheets. Setelah pembelajaran berakhir pada setiap pertemuan peneliti mengadakan diskusi dengan para observer untuk mengetahui temuan - temuan selama tindakan pembelajaran sebagai bahan refleksi.Pada Tahap refleksi ,Langkahlangkah yang dilakukan pada tahap ini adalah: 1) Merefleksi tiap hal yang diperoleh dengan menggunakan lembar observasi, yaitu keaktifan siswa dalam menyelesaikan tugas menggunakan aplikasi liveworksheets,2) Menilai dan mempelajari perkembangan hasil pekerjaan siswa yang telah diberikan pada siklus I, serta nilai akhir pada siklus I. Untuk selanjutnya dibuat rencana perbaikan dan penyempurnaan siklus I pada siklus berikutnya. Gambaran umum siklus II, dilaksanakan berdasarkan hasil pelaksanaan siklus I, inti dari pelaksanaan siklus II adalah untuk memperbaiki pelaksanaan siklus I. Langkah-langkah yang dilakukan kurang lebih sama dengan siklus I yaitu perencanaan ulang, tindakan dan pengamatan. Teknik Pengumpulan Data :1) Data mengenai aktivitas belajar mengajar diperoleh pada saat dilaksanakan tindakan dengan menggunakan lembar observasi. 2) Data mengenai hasil belajar diperoleh dari hasil evaluasi tiap siklus dengan menggunakan tes hasil belajar .3) Data tentang tanggapan siswa terhadap media pembelajaran yang diperoleh dengan mengedarkan angket.

Teknik Analisis Data ,Data yang terkumpul dianalisis secara kuantitatif dan kualitatif. Analisis kualitatif dilaksanakan sesuai dengan kecenderungan yang terjadi pada setiap siklus dengan melakukan penilaian secara verbal (aktivitas dan sikap yang teramati atau diambil dari data observasi). Namun metode kualitatif belum dapat memberikan jawaban yang cukup tentang hasil belajar yang diperoleh siswa. Olehnya itu digunakan metode kuantitatif dengan analisis deskriptif untuk mendeskripsikan skor rata-rata dan persentase. Dengan metode ini diharapkan hasil belajar siswa dapat diungkap. Kriteria yang digunakan untuk menentukan kategori hasil belajar IPA adalah berdasarkan teknik kategorisasi yang ditetapkan oleh Departemen Pendidikan Nasional yang dinyatakan pada tabel dibawah ini.

Indikator Keberhasilan :Kriteria keberhasilan penelitian tindakan kelas ini adalah terjadinya peningkatan hasil belajar siswa dalam IPA, baik ditinjau dari hasil tes setiap akhir siklus maupun dari segi keaktifan siswa dalam mengikuti pembelajaran. Menurut ketentuan di SMP Negeri 17 Malang bahwa siswa dikatakan tuntas belajar jika memperoleh skor minimal 75 dari skor ideal, dan tuntas secara klasikal apabila minimal $85 \%$ dari jumlah siswa yang telah tuntas belajar. Indikator dapat dilihat pada tabel dibawah ini.

\section{HASIL DAN PEMBAHASAN}

\section{Hasil}

Tujuan Penelitian ini untuk meningkatkan hasil belajar siswa di Kelas IX A SMP Negeri 17 Malang pada pembelajaran IPA materi Kemagnetan dengan menggunakan media google Classroom berbantu liveworksheets.Penulis adalah guru yang mengampu mata pelajaran IPA di kelas IX A sehingga memahami karaktristik siswa dalam hal pencapaian hasil belajar.Berdasarkan pengalaman peneliti yang mengajar di kelas IX A pada semester gasal Tahun Pelajaran 2021/2022 dengan menggunakan media Google Classroom dan Google Formulir, hasil belajar siswa rata-rata masih belum mecapai standart KKM yaitu (75). Hal itu terbukti dengan diperolehnya hasil rata -rata Nilai Ulangan Harian $(71,74)$, rata -rata Nilai PTS (70,7), dan rata - rata Nilai PAS (70,2). Untuk itu peneliti mencoba mencari solusi dengan menggunakan media lain dengan harapan akan memberi motivasi kepada siswa untuk lebih tertarik belajar dan akhirnya bisa meningkatkan hasil belajarnya sehingga minimal bisa mencapai KKM dan syukur bila bisa mencapai diatas KKM.

1. Hasil Penelitian Siklus I 
Pada tahap perencanaan peneliti sudah mempersiapkan semua kelengkapan penelitian berupa, LKPD, lembar observasi, instrument soal evaluasi, RPP dengan penerapan media google classroom berbantu liveworksheets untuk setiap siklus sesuai kebutuhan, semua kelengkapan penelitian dapat di lihat pada lampiran .Secara garis besar penerapan media google classroom berbantu liveworksheets dapat dijabarkan sebagai berikut : 1). Guru mempersilahkan peserta didik membuka google classroomnya dan membaca serta mengikuti semua petunjuk yang ada, 2). Peserta didik membuka link liveworksheets dan mengerjakan LKPD secara mandiri , 3). Guru memantau hasil kerja peserta didik melalui link yang sudah tersedia , 4). Guru berkeliling mengedarkan daftar hadir siswa yang mengikuti pembelajaran pertemuan I atau II pada siklus I. 5). Peserta didik secara acak diberi kesempatan maju untuk mempresentasikan hasil pekerjaannya. 6). Guru dan peserta didik melakukan refleksi dan membuat kesimpulan, 7). Observer melakukan observasi terhadap pelaksanaan pembelajaran pertemuan Iatau II pada siklus I dengan mengisi lembar observasi.

Pada tahap Pelaksanaan Tindakan peneliti melakukan kegiatan pembelajaran sesuai dengan rencana pelaksanaan pembelajaran yang telah dibuat. Untuk dapat menyesuaikan rencana pelaksanaan pembelajaran dalam penyampaian materi, termasuk didalamnya pembelajaran dengan menggunakan media google classroom berbantu liveworksheets untuk materi kemagnetan dilaksanakan 2 kali pertemuan untuk penyampaian materi dan 1 kali pertemuan untuk evaluasi. Proses pembelajaran siklus I dilaksanakan pada tanggal 13 januari 2022 dan 14 Januari 2022 sedangkan evaluasi siklus I dilaksanakan pada tanggal 18 Januari 2022. Langkah yang dilakukan seperti yang dijabarkan pada perencanaan di atas.

Pada tahap Observasi dan Evaluasi ,hasil observasi diperoleh dari hasil pengamatan yang dilakukan oleh observer yang dilakukan pada setiap kali pertemuan pembelajaran dengan mengisi lembar observasi aktivitas siswa untuk merekam jalannya proses pembelajaran dan berdasarkan penilaian siswa mengerjakan LKPD.

Berdasarkan hasil observasi terhadap aktivitas siswa setelah dianalisa diperoleh data sebagai berikut :

Tabel 1. Hasil Observasi Aktivitas Siswa Pada Siklus I

\begin{tabular}{|c|c|c|c|c|c|c|c|c|c|}
\hline \multirow{2}{*}{$\begin{array}{c}\text { Pertemua } \\
\mathrm{n}\end{array}$} & \multicolumn{6}{|c|}{ Jumlah skor yang tampak } & \multirow{2}{*}{$\begin{array}{c}\Sigma \\
\text { Skor } \\
\text { aktivita } \\
\text { s }\end{array}$} & \multirow{2}{*}{$\begin{array}{c}\text { Rata- } \\
\text { rata } \\
\text { Aktivita } \\
\text { s }\end{array}$} & \multirow{2}{*}{$\begin{array}{c}\text { Kategor } \\
\text { i }\end{array}$} \\
\hline & 1 & 2 & 3 & 4 & 5 & 6 & & & \\
\hline Pertama & $\begin{array}{c}89,8 \\
4\end{array}$ & $\begin{array}{c}92,9 \\
7\end{array}$ & $\begin{array}{c}75,7 \\
8\end{array}$ & $\begin{array}{c}82,8 \\
1\end{array}$ & $\begin{array}{c}83.5 \\
9\end{array}$ & $\begin{array}{c}81,2 \\
5\end{array}$ & 506,24 & 84.38 & Aktif \\
\hline Kedua & $\begin{array}{c}90,3 \\
2 \\
\end{array}$ & $\begin{array}{c}93,5 \\
5\end{array}$ & $\begin{array}{c}75,8 \\
1 \\
\end{array}$ & $\begin{array}{c}83,0 \\
3\end{array}$ & $\begin{array}{c}83,8 \\
7\end{array}$ & $\begin{array}{c}81,4 \\
5\end{array}$ & 508,03 & 84,68 & Aktif \\
\hline
\end{tabular}

Dari tabel di atas dapat dilihat bahwa aktivitas belajar siswa pada siklus I pertemuan 1 diperoleh rata-rata sebesar 84,38 dengan kategori aktif pertemuan 2 diperoleh rata-rata sebesar 84,68 dengan kategori aktif.

Berdasarkan hasil penilaian terhadap LKPD yang dikerjakan siswa setelah dianalisa diperoleh data sebagai berikut :

Tabel 2. Hasil Mengerjakan LKPD Siswa Pada Siklus I

\begin{tabular}{|c|c|c|c|c|c|}
\hline Pertemuan & Tanggal & LKPD & Materi & $\begin{array}{c}\Sigma \\
\text { Skor Nilai }\end{array}$ & Rata-rata \\
\hline I & $13-1-22$ & I & Konsep gaya magnet & 240,4 & 7.51 \\
\hline II & $14-1-22$ & II & $\begin{array}{c}\text { Medan Magnet dan } \\
\text { Teori kemagnetan } \\
\text { Bumi }\end{array}$ & 208,9 & 6.74 \\
\hline \multicolumn{7}{|c|}{ Rata -rata Siklus I } & 7,25 \\
\hline
\end{tabular}


Dari tabel di atas dapat dilihat bahwa nilai siswa dalam mengerjakan LKPD pada siklus I pertemuan 1 diperoleh rata-rata sebesar 7,51 dan pertemuan 2 diperoleh rata-rata sebesar 6,74 sehingga kalau dirata rata pada siklus I Penguasaan mengerjakan LKPD sebesar 7,25.

Berdasarkan Evaluasi Hasil Belajar setelah dianalisis diperoleh data sebagai berikut :

Tabel 3. Hasil Evaluasi Belajar Siswa Pada Siklus I

\begin{tabular}{|l|l|c|}
\hline No & \multicolumn{1}{|c|}{ Uraian } & Hasil \\
\hline 1 & Nilai Terendah & 53 \\
\hline 2 & Nilai Tertinggi & 93 \\
\hline 3 & Rata-rata & 82,28 \\
\hline 4 & Jumlah siswa yang tuntas & 22 \\
\hline 5 & Jumlah siswa yang ikut tes & 29 \\
\hline 6 & Persentase Ketuntasan Kalsikal & $75,68 \%$ \\
\hline
\end{tabular}

Dari tabel di atas dapat dilihat bahwa ketuntasan belajar secara klasikal yang dicapai sebesar 75,68 \% dengan nilai rata-rata sebesar 82,28. Hasil ini belum mencapai ketuntasan belajar secara klasikal sehingga pembelajaran dilanjutkan ke siklus berikutnya.

Pada Tahap Refleksi berdasarkan analisis hasil observasi pada siklus I, jumlah siswa yang tuntas secara klasikal sebesar 75,68 \% berarti masih dibawah standar ketuntasan klasikal yang ditentukan. Oleh karena itu peneliti melanjutkan ke siklus berikutnya. Dalam siklus I ini terdapat kekurangan/kelemahan yang perlu untuk diperhatikan dan diperbaiki pada kegiatan siklus II diantaranya: 1). Keaktifan siswa masih belum merata dalam proses pembelajaran, 2).Pada saat mengerjakan LKPD siswa mengerjakan secara mandiri ,3).Guru melaksanakan proses pembelajaran dengan menggunakan media google cassroom berbantu liveworksheets dengan lebih maksimal dengan meminta siswa bekerja secara kelompok

\section{Hasil Penelitian Siklus II}

Proses pembelajaran pada siklus II diawali dengan pemberian umpan balik dari hasil evaluasi yang diberikan. Kegiatan pada siklus didasarkan pada rekomendasi yang dibuat dari hasil siklus I.

Pada Tahap Perencanaan peneliti mempersiapkan semua kelengkapan penelitian baik berupa, LKPD, lembar observasi, instrument soal evaluasi, RPP dengan menggunakan media google classroom berbantu livewokrsheets dapat dijabarkan sebagai berikut :1). Guru mempersilahkan peserta didik membuka google classroomnya dan membaca serta mengikuti semua petunjuk yang ada, 2). Peserta didik membuka link liveworksheets dan mengerjakan LKPD secara kelompok, 3). Guru memantau hasil kerja peserta didik melalui link yang sudah tersedia, 4). Guru berkeliling mengedarkan daftar hadir siswa yang mengikuti pembelajaran pertemuan I atau II pada siklus II, 5). Peserta didik secara kelompok diberi kesempatan maju untuk mempresentasikan hasil pekerjaannya, 6). Guru dan peserta didik melakukan refleksi dan membuat kesimpulan, 7). Observer melakukan observasi terhadap pelaksanaan pembelajaran pertemuan I atau II pada siklus II dengan mengisi lembar observasi.

Pada Tahap Pelaksanaan Tindakan peneliti melakukan kegiatan pembelajaran sesuai dengan rencana pelaksanaan pembelajaran yang telah dibuat. Untuk dapat menyesuaikan rencana pelaksanaan pembelajaran dalam penyampaian materi, termasuk didalamnya pembelajaran dengan menggunakan media google classroom berbantu liveworksheets, untuk materi kemagnetan dilaksanakan 2 kali pertemuan untuk penyampaian materi dan 1 kali pertemuan untuk evaluasi. Proses pembelajaran siklus II dilaksanakan pada tanggal 20 Januari 2022 dan 21 Januari 2022 sedangkan evaluasi siklus II dilaksanakan pada tanggal 27 Januari 2022.Setelah melaksanakan Evaluasi II ,peserta didik di persilahkan mengisi angket yang dikirim melalui google Formulir.

Pada Tahap Observasi dan Evaluasi ,hasil observasi diperoleh dari hasil pengamatan yang dilakukan oleh observer yang dilakukan pada setiap kali pertemuan pembelajaran dengan 
Vol. 2 No. 1 Februari 2022, e-ISSN : 2797-0140 | p-ISSN : 2797-0590

mengisi lembar observasi aktivitas siswa untuk merekam jalannya proses pembelajaran dan berdasarkan penilaian siswa mengerjakan LKPD.

Berdasarkan hasil observasi terhadap aktivitas siswa setelah dianalisa diperoleh data sebagai berikut :

Tabel 4. Hasil Observasi Aktivitas Siswa Pada Siklus II

\begin{tabular}{|c|c|c|c|c|c|c|c|c|c|}
\hline \multirow{2}{*}{$\begin{array}{c}\text { Pertemua } \\
\mathrm{n}\end{array}$} & \multicolumn{6}{|c|}{ Jumlah skor yang tampak } & \multirow{2}{*}{$\begin{array}{c}\Sigma \\
\text { Skor } \\
\text { aktivita } \\
\text { s }\end{array}$} & \multirow{2}{*}{$\begin{array}{c}\text { Rata- } \\
\text { rata } \\
\text { Aktivita } \\
\text { s }\end{array}$} & \multirow{2}{*}{$\begin{array}{c}\text { Kategor } \\
\text { i }\end{array}$} \\
\hline & 1 & 2 & 3 & 4 & 5 & 6 & & & \\
\hline Pertama & $\begin{array}{c}98,3 \\
8\end{array}$ & $\begin{array}{c}95,1 \\
6\end{array}$ & $\begin{array}{c}87,1 \\
0\end{array}$ & $\begin{array}{c}85.4 \\
8\end{array}$ & $\begin{array}{c}88,7 \\
1\end{array}$ & $\begin{array}{c}94,3 \\
5\end{array}$ & 549,18 & 91,35 & $\begin{array}{c}\text { Sangat } \\
\text { Aktif }\end{array}$ \\
\hline Kedua & $\begin{array}{c}99,1 \\
7\end{array}$ & $\begin{array}{c}95,8 \\
3\end{array}$ & $\begin{array}{c}87,5 \\
0\end{array}$ & $\begin{array}{c}86,6 \\
7\end{array}$ & $\begin{array}{c}90,0 \\
0\end{array}$ & $\begin{array}{c}95,0 \\
0\end{array}$ & 554,17 & 92,36 & $\begin{array}{c}\text { Sangat } \\
\text { Aktif }\end{array}$ \\
\hline
\end{tabular}

Dari tabel di atas dapat dilihat bahwa aktivitas belajar siswa pada siklus II pertemuan 1 diperoleh rata-rata sebesar 91,35 dengan kategori sangat sktif dan pertemuan 2 diperoleh ratarata sebesar 92,36 dengan kategori sangat aktif. Berdasarkan hasil penilaian terhadap LKPD yang dikerjakan siswa setelah dianalisa diperoleh data sebagai berikut :

Tabel 5. Hasil Mengerjakan LKPD Siswa Pada Siklus II

\begin{tabular}{|c|c|c|c|c|c|}
\hline Pertemuan & Tanggal & LKPD & Materi & $\begin{array}{c}\Sigma \\
\text { Skor Nilai }\end{array}$ & Rata-rata \\
\hline I & $20-1-22$ & III & $\begin{array}{c}\text { Induksi magnet dan } \\
\text { Gaya Lorenz }\end{array}$ & 233 & 7.51 \\
\hline II & $21-1-22$ & IV & $\begin{array}{c}\text { Induksi } \\
\text { Elektromagnetik }\end{array}$ & 236 & 7.86 \\
\hline \multicolumn{7}{|c|}{ Rata -rata Siklus II } \\
\hline
\end{tabular}

Dari tabel di atas dapat dilihat bahwa nilai siswa dalam mengerjakan LKPD pada siklus II pertemuan 1 diperoleh rata-rata sebesar 7,51 dan pertemuan 2 diperoleh rata-rata sebesar 7.86 sehingga kalau dirata rata pada siklus II Penguasaan mengerjakan LKPD sebesar 7,68. Berdasarkan Evaluasi Hasil Belajar setelah dianalisis diperoleh data sebagai berikut :

Tabel 6. Ringkasan Hasil Evaluasi Pada Siklus II

\begin{tabular}{|l|l|c|}
\hline No & \multicolumn{1}{|c|}{ Uraian } & Hasil \\
\hline 1 & Skor Terendah & 40 \\
\hline 2 & Skor Tertinggi & 90 \\
\hline 3 & Rata-rata & 84,5 \\
\hline 4 & Jumlah siswa yang tuntas & 28 \\
\hline 5 & Jumlah siswa yang ikut tes & 32 \\
\hline 6 & Persentase Ketuntasan Klasikal & $87.5 \%$ \\
\hline
\end{tabular}

Dari tabel di atas dapat dilihat bahwa ketuntasan belajar secara klasikal yang dicapai sebesar $87.50 \%$ dengan nilai rata-rata sebesar 84,5 Hasil ini sudah mencapai ketuntasan belajar secara klasikal sehingga pembelajaran dihentikan.

Hasil Penelitian penggunaan media Google Classroom Berbantu Liveworksheets dapat dibuat ringkasan sebagai berikut :

1. Observasi Aktivitas Pembelajaran Siswa dapat dilihat pada tabel berikut : 
Tabel 7. Ringkasan Hasil Observasi Aktivitas Pembelajaran Siswa

\begin{tabular}{|l|l|l|l|}
\hline \multirow{2}{*}{ Siklus } & \multicolumn{2}{c|}{ Skor Rata-Rata } & \multirow{2}{*}{ Rata - Rata } \\
\cline { 2 - 4 } & Pertemuan I & Pertemuan II & \\
\hline I & 84,38 & 84,68 & 84,53 \\
\hline II & 91,53 & 92,36 & 91,95 \\
\hline
\end{tabular}

Dari tabel diatas dapat dilihat bahwa aktivitas belajar siswa pada siklus I meningkat sebesar 7,42\% pada siklus II.

2. Hasil Penguasaan mengerjakan LKPD dapat dilihat pada tabel berikut :

Tabel 8. Ringkasan Hasil Penguasaan mengerjakan LKPD

\begin{tabular}{|l|l|l|l|}
\hline \multirow{2}{*}{ Siklus } & \multicolumn{2}{|c|}{ Skor Rata -Rata } & \multirow{2}{*}{ Rata - Rata } \\
\cline { 2 - 3 } & Pertemuan I & Pertemuan II & \\
\hline I & 7,51 & 6,74 & 7,25 \\
\hline II & 7,51 & 7,86 & 7,68 \\
\hline
\end{tabular}

Dari tabel diatas dapat dilihat bahwa penguasaan mengerjakan LKPD pada siklus I meningkat sebesar $0,43 \%$ pada siklus II.

3. Hasil Evaluasi Siswa

Terkait dengan hasil evaluasi pada siklus I dan II dapat dilihat dari diagram batang dan tabel dibawah ini :

Tabel 10. Ringkasan Hasil Evaluasi Siswa

\begin{tabular}{|l|l|l|l|l|}
\hline Pertemuan & Tanggal & Evaluasi & Nilai Rata -rata & $\begin{array}{l}\text { Prosentase ketuntasan } \\
\text { Klasikal }\end{array}$ \\
\hline I & $18-1-2022$ & I & 82,28 & $75,08 \%$ \\
\hline II & $27-1-2022$ & II & 84,50 & $87,5 \%$ \\
\hline
\end{tabular}

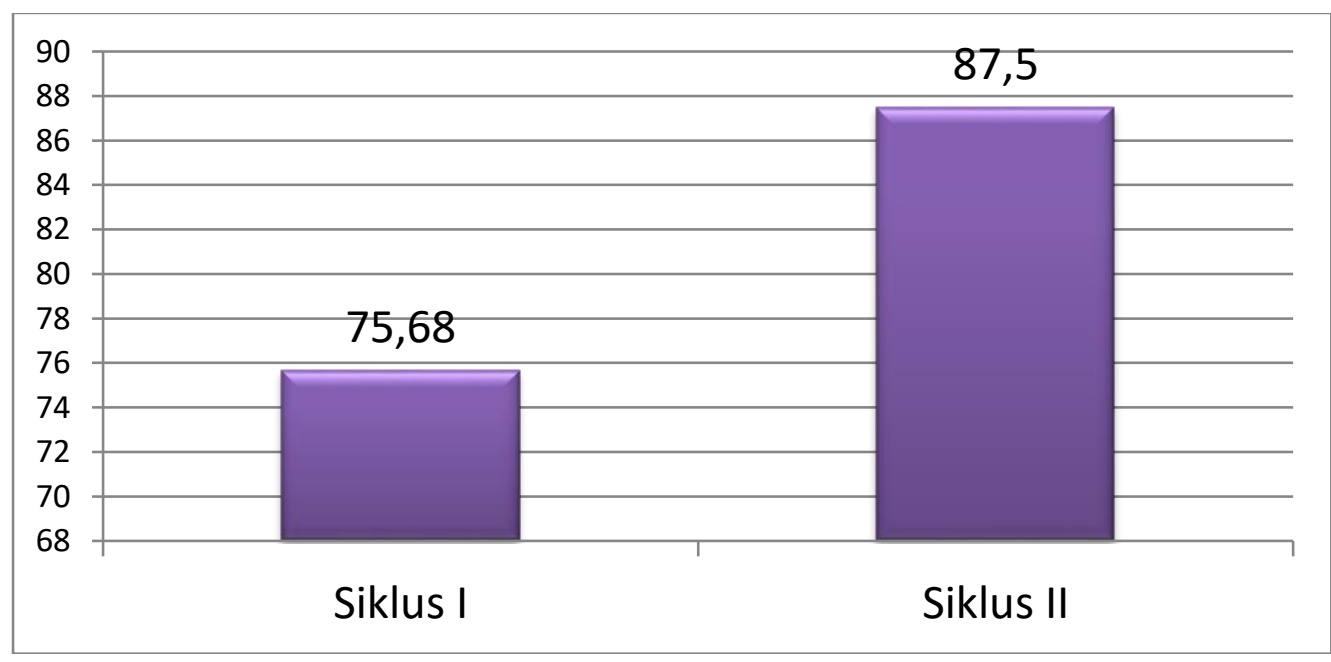

Gambar 1. Diagram Prosentase Evaluasi Hasil belajar

Dari tabel dan diagram batang diatas dapat dilihat bahwa hasil Evaluasi Belajar pada siklus I meningkat sebesar 11,68\% pada siklus II

4. Angket Tanggapan Siswa terhadap Aplikasi Liverworksheets. Berdasarkan Hasil Angket setelah dianalisis diperoleh data sebagai berikut : 
Tabel 11. Hasil Angket Tanggapan Siswa Terhadap Aplikasi Liveworksheets

\begin{tabular}{|c|c|c|c|c|c|c|c|c|}
\hline \multirow{2}{*}{ Instrumen } & \multicolumn{5}{|c|}{ Jumlah skor yang tampak } & \multirow{2}{*}{$\begin{array}{c}\Sigma \\
\text { Skor tanggapan } \\
\end{array}$} & \multirow{2}{*}{ Rata-rata tanggapan } & \multirow{2}{*}{ Kategori } \\
\hline & 1 & 2 & 3 & 4 & 5 & & & \\
\hline 1 & 1 & 1 & 1 & 14 & 15 & 137 & 4,28 & SB \\
\hline 2 & - & 5 & 5 & 10 & 12 & 125 & 3,91 & B \\
\hline 3 & 7 & 2 & 8 & 8 & 7 & 102 & 3,19 & $\mathrm{~B}$ \\
\hline 4 & 2 & 6 & 5 & 9 & 10 & 115 & 3,59 & $\mathrm{~B}$ \\
\hline 5 & 2 & 1 & - & 10 & 19 & 139 & 4,34 & SB \\
\hline 6 & 1 & - & - & 7 & 24 & 149 & 4,66 & SB \\
\hline 7 & 3 & 3 & 6 & 9 & 10 & 115 & 3,59 & B \\
\hline 8 & 5 & 4 & 5 & 10 & 8 & 108 & 3,38 & B \\
\hline 9 & 3 & 4 & 8 & 13 & 4 & 107 & 3,34 & B \\
\hline 10 & 3 & 1 & 5 & 11 & 12 & 124 & 3,38 & $B$ \\
\hline & & & & & & 1221 & 38,16 & \\
\hline & & $\mathrm{ta}-$ & rat: & & & 122,1 & 3,82 & \\
\hline
\end{tabular}

Tabel 12. Prosentase Tanggapan Siswa Terhadap Aplikasi Liveworksheets

\begin{tabular}{|l|l|l|l|}
\hline No & Kategori & Jumlah siswa & Prosentase \\
\hline 1 & Sangat Baik (SB) & 16 & $16 / 32 * 100 \%=50 \%$ \\
\hline 2 & Baik (B) & 11 & $11 / 32 * 100 \%=34,38 \%$ \\
\hline 3 & Cukup Baik (CB) & 5 & $5 / 32 * 100 \%=15,62 \%$ \\
\hline 4 & Kurang Baik (KB) & - & - \\
\hline Prsentase Klasikal (B dan SB) & 27 & $27 / 32 * 100 \%=84,45 \%$ \\
\hline
\end{tabular}

Terkait tanggapan siswa terhadap penggunaan media google classroom berbantu liveworksheets dapat dilihat dari rinciannya di bawah ini :

Tabel 13. Ringkasan Tanggapan siswa terhadap penggunaan Aplikasi Liveworksheets

\begin{tabular}{|l|l|l|l|l|}
\hline Instrumen & $\begin{array}{l}\mid c \\
\text { Skor } \\
\text { tanggapan }\end{array}$ & $\begin{array}{l}\text { Rata-rata } \\
\text { skor }\end{array}$ & Katagori & $\begin{array}{l}\text { Prosen- } \\
\text { Tase }\end{array}$ \\
\hline $\begin{array}{l}\text { Guru menggunakan Aplikasi } \\
\text { liveworksheets dalam } \\
\text { pembelajaran }\end{array}$ & 137 & 4,28 & SB & $85,63 \%$ \\
\hline $\begin{array}{l}\text { Guru memberikan petunjuk secara } \\
\text { jelas Dalam menggunakan aplikasi } \\
\text { liveworksheets }\end{array}$ & 125 & 3,91 & B & $78,13 \%$ \\
\hline $\begin{array}{l}\text { Penggunaan aplikasi } \\
\text { liveworksheets lebih } \\
\text { mempermudah memahami materi } \\
\text { kemagnetan }\end{array}$ & 102 & 3,19 & B & $63,75 \%$ \\
\hline $\begin{array}{l}\text { aplikasi liveworksheets dapat } \\
\text { dikerjakan semua dengan mudah }\end{array}$ & 125 & 3,59 & B & $71,88 \%$ \\
\hline $\begin{array}{l}\text { Aplikasi liveworksheets bisa } \\
\text { digunakan untuk materi yang lain }\end{array}$ & 139 & 4,34 & SB & $86,88 \%$ \\
\hline $\begin{array}{l}\text { Penilaian hasil belajar langsung } \\
\text { bisa dilihat setelah selesai } \\
\text { mengerjakan }\end{array}$ & 149 & 4.66 & SB & $93,13 \%$ \\
\hline $\begin{array}{l}\text { kamu mentargetkan } \\
\text { tes/ulangan yang }\end{array}$ & 115 & 3,59 & B & $71,88 \%$ \\
\hline
\end{tabular}


Vol. 2 No. 1 Februari 2022, e-ISSN : 2797-0140 | p-ISSN : 2797-0590

\begin{tabular}{|l|l|l|l|l|}
\hline $\begin{array}{l}\text { lebih baik jika dibandingkan nilai } \\
\text { tes sebelumnya }\end{array}$ & & & & \\
\hline $\begin{array}{l}\text { perasaanmu senang setelah } \\
\text { mencoba mengerjakan aplikasi } \\
\text { liveworksheets }\end{array}$ & 108 & 3,38 & $\mathrm{~B}$ & $67,5 \%$ \\
\hline $\begin{array}{l}\text { Jika dari dua kali hasil evaluasi nilai } \\
\text { yang kamuperoleh ternyata kurang } \\
\text { baik (belum mencapai KKM), } \\
\text { kamu tetap bersemangat } \\
\text { menggunakan aplikasi } \\
\text { liveworksheets }\end{array}$ & 107 & 3,34 & $\mathrm{~B}$ & $66,88 \%$ \\
\hline $\begin{array}{l}\text { aplikasi liveworksheets bisa } \\
\text { digunakan untuk menjawab } \\
\text { pertanyaan essay }\end{array}$ & 124 & 3,88 & $\mathrm{~B}$ & $77,5 \%$ \\
\hline Rata-Rata & 122,1 & 3,82 & $\mathrm{~B}$ & $76,31 \%$ \\
\hline
\end{tabular}

Dari tabel di atas dapat dilihat bahwa tanggapan siswa terhadap aplikasi liveworksheets secara klasikal untuk instrumen 1 sampai 10 dicapai sebesar 84, 45\% dengan nilai rata-rata sebesar 3,82 . Prosentase tertinggi terdapat pada instrumen nomor 6 yaitu : Penilaian hasil belajar langsung bisa dilihat setelah selesai mengerjakan sebesar 93,13\% sedang prosentase terendah terdapat pada instrumen nomor 3 yaitu : Penggunaan aplikasi liveworksheets lebih mempermudah memahami materi kemagnetan sebesar 63,75\%

Pada Tahap Refleksi berdasarkan analisis hasil observasi pada siklus II , jumlah siswa yang tuntas secara klasikal sebesar $87,50 \%$ berarti sudah memenuhi standar ketuntasan klasikal yang ditentukan. Oleh karena itu peneliti menghentikan penelitian ke siklus berikutnya sesuai perencanaan.

\section{Pembahasan}

Penelitian tindakan kelas ini dilaksanakan sebagai upaya untuk meningkatkan hasil belajar mata pelajaran IPA dalam pada materi Kemagnetan melalui media google classroom berbantu liveworksheets di kelas IX.A semester genap pada SMPN 17 Malang tahun pelajaran 2021/2022. Setelah melihat tabel pada hasil penelitian maka terlihat : 1). Ada kenaikan aktivitas siswa dari siklus I ke siklus II. Pada siklus I rata-ratanya sebesar 84,53 masuk dalam katagori aktif dan pada siklus II rata - ratanya sebesar 91, 95 dan masuk dalam katagori Sangat Aktif.2).Ada kenaikan penguasaan mengerjakan LKPD dari siklus I ke siklus II. Pada siklus I rata-ratanya sebesar 7,25 belum masuk dalam katagori tuntas belajar dan pada siklus II rata ratanya sebesar 7,68 sudah masuk dalam katagori Tuntas Belajar.3). Hasil evaluasi dari siklus I dan II dimana nilai yang mereka peroleh sudah mencapai tingkat ketuntasan belajar. Dan melebihi tingkat ketuntasan belajar secara klasikal (85\%). Adanya kenaikan hasil evaluasi dari Siklus I ke Siklus II disebabkan adanya perubahan tindakan yaitu pada siklus I LKPD dikerjakan secara mandiri sedang pada siklus II LKPD dikerjakan secara kelompok.4). Penggunaan media googleclassroom berbantu liveworksheets dapat meningkatkan hasil belajar siswa .5).Tanggapan siswa terhadap penggunaan Aplikasi Liveworksheets, dapat dilihat untuk instrumen 1, 2, 5, 6, dan 10 tanggapan siswa sudah mencapai diatas $75 \%$,sedangkan untuk instrumen 3,4,7,8 dan 9 kurang dari 75\%, tetapi kalau dilihat keseluruhan sudah mencapai 76,31 $\%$. Penggunaan aplikasi liveworksheets di minati siswa karena hasil penilaian langsung bisa dilihat seperti terlihat di tabel 13 yaitu sebesar 93,13\% dan tanggapan secara klasikal sebesar $84,45 \%$,dari 32 siswa 27 siswa masuk dalam kategori Baik dan Sangat Baik ( kategori sangat baik 16 siswa, baik 11 siswa ), kategori cukup 5 siswa sedang kategori kurang tidak ada.

Hasil penelitian ini sudah sudah bisa menunjukkan bahwa penggunaan aplikasi liveworksheets menjadi hal baru bagi siswa dan menarik minat siswa untuk bisa menggunakan aplikasi liveworkheets tersebut. Pada perhitungan analisa siklus I dan II terjadi peningkatan 
nilai sebesar 11,82\%.Hal ini diperkuat oleh hasil penelitian beberapa peneliti diantaranya, 1). Prabowo, A. (2021).yang menyatakan bahwa "Penggunaan Liveworksheet dengan Aplikasi Berbasis Web dapat meningkatkan Hasil Belajar Peserta Didik". 2). Widiyani, A., \& Pramudiani, P.(2021) yang menyatakan bahwa "LKPD berbasis software liveworksheet pada materi PPKn pada subtema "Hak" adalah layak dan menarik untuk digunakan sebagai media evaluasi pembelajaran bagi siswa kelas V" 3). Nadifatinisa, N., \& Sari, P. M. (2021). menyatakan bahwa "Pengembangan LKPD berbasis HOTS menggunakan Live worksheet pada Pembelajaran IPA Materi Ekosistem layak digunakan sebagai sumber belajar peserta didik kelas V di Sekolah Dasar".Dalam web pakarkominikasi. Com(2021), menyatakan bahwa "Di dalam Teori e-learning menggambarkan prinsip-prinsip ilmu kognitif pembelajaran multimedia yang efektif dengan menggunakan teknologi pendidikan elektronik. Hasil penelitian dan teori kognitif menunjukkan bahwa pemilihan modalitas multimedia yang sesuai secara bersamaan dapat meningkatkan pembelajaran. Teori ini merupakan pengembangan dari teori cognitive load yang dikembangkan oleh J. Sweller”. Menurut Wati, D. A., Hakim, L., \& Lia, L.(2022) menyatakan bahwa "Berdasarkan hasil analisis data dapat disimpulkan bahwa eLKPD interaktif Hukum Newton berbasis mobile learning menggunakan live worksheets di SMA dinyatakan valid, praktis dan mempunyai dampak potensial terhadap hasil belajar pada ranah kognitif (ngain 0,58 pada tingkat sedang) dan motivasi belajar (rata-rata 49,8 pada tingkat sedang), sehingga layak digunakan pada proses pembelajaran". Dua hal diatas mendukung dan memperkuat hasil penelitian ini bahwa penggunaan aplikasi liveworksheets menjadi hal baru bagi siswa dan menarik minat siswa untuk bisa menggunakan aplikasi liveworkheets tersebut.

\section{KESIMPULAN}

Dari hasil penelitian dan pembahasan di atas dapatlah kami simpulkan:

1. Proses penggunaan google cassroom berbantu liveworksheets diawali guru menyiapkan link pada aplikasi liveworksheets, menyusun soal dan evaluasi kemudian menyusun petunjuk kerja pada googleclassroom dan siswa membuka link tersebut kemudian mengerjakan LKPD serta terakhir langsung bisa melihat nilainya, membuat siswa aktif ,senang dan tertarik serta dapat meningkatkan hasil belajar IPA materi kemagnetan pada siswa kelas IX.A semester genap di SMP Negeri 17 Malang Tahun Pelajaran 2021/2022.

2. Penggunaan media google cassroom berbantu liveworksheets dapat meningkatkan hasil belajar IPA materi kemagnetan pada siswa kelas IX.A semester genap di SMP Negeri 17 Malang Tahun Pelajaran 2021/2022.

\section{DAFTAR PUSTAKA}

Hazlita, S, JIRA. 2021. Jurnal Inovasi dan Riset Akademik, diunduh tanggal 10 Desember 2021 Keputusan Balitbang dan Perbukuan Kemendikbud No 018/H/KR/2020. 2020. Ringkasan KI dan KD K-13 : Jakarta

Lisnuriyanih,Siska.2021. Membuat Bahan Ajar Inovatif dengan Aplikasi Liveworksheet. diunduh tanggal 10 Desember 2021.

Nadifatinisa, N., \& Sari, P. M. (2021). Pengembangan Lembar Kerja Peserta Didik (LKPD) Berbasis Higher Order Thingking Skill (HOTS) Pada Pembelajaran IPA Materi Ekosistem Kelas V. Jurnal Pedagogi dan Pembelajaran, 4(2).

Prabowo, Andi.2021. Penggunaan Liveworksheet dengan Aplikasi Berbasis Web untuk Meningkatkan Hasil Belajar Peserta Didik. Jurnal Pendidikan dan Teknologi Indonesia, 1(10), 383-388.

Wati, D. A., Hakim, L., \& Lia, L.2022. Development Of Newton Law Interactive E-Lkpd Based On Mobile Learning Using Live Worksheets In High School. Jurnal Pendidikan Fisika, 10(2), 72-80.

Widiyani, A., \& Pramudiani, P. 2021. Pengembangan Lembar Kerja Peserta Didik (LKPD) Berbasis Software Liveworksheet pada Materi PPKn. : Jurnal Riset Pedagogik, 5(1), 132-141. 